\title{
Geology and Coal
}

\section{Resources of the}

\section{ittle Susitna District}

\section{Matanuska Coal Field}

\section{Alaska}

FARRELL F. BARNES and DANIEL SOKOL

I I E RAL RESOURCES OF A LASKA

E O L O G I C A L S U R VEY B ULLE T I N 1058-D

he results of subsurface exploration

or coal in the western part of the

Matanuska Valley

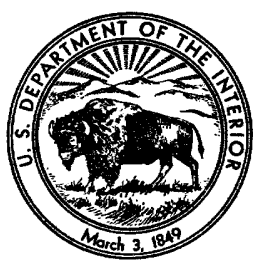


UNITED STATES DEPARTMENT OF THE INTERIOR FRED A. SEATON, Secretary

\author{
GEOLOGIGAL SURVEY
}

Thomas B. Nolan, Director Washington 25, D. C. 


\section{CONTENTS}

\begin{tabular}{|c|c|}
\hline & Page \\
\hline Abstract_. & 121 \\
\hline Introduction & 121 \\
\hline General features. & 123 \\
\hline Stratigraphy & 124 \\
\hline Structure & 125 \\
\hline - & 128 \\
\hline Character and distribution & 128 \\
\hline Subsurface exploration & 128 \\
\hline 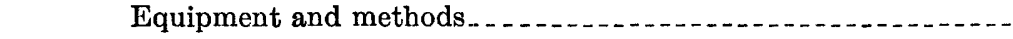 & 128 \\
\hline Interpretation of results & 130 \\
\hline Details of coal localities & 132 \\
\hline Locality $1, \ldots$ & 132 \\
\hline - & 133 \\
\hline - & 135 \\
\hline Locality 4 & 136 \\
\hline Locality 5 & 137 \\
\hline Houston area & 137 \\
\hline Immary of coal resources & 138 \\
\hline ces cited.... & 138 \\
\hline
\end{tabular}

\section{ILLUSTRATIONS}

[Plates 7-11 are in pocket]

Plate 7. Geologic map of the Little Susitna district, Matanuska coal field, Alaska.

8. Map and sections of coal locality 4.

9. Graphic logs of power-auger drill holes in the Little Susitna district.

10. Map and sections of coal locality 2 .

11. Map and sections of coal locality 3 .

Frgure 36. Index map of south-central Alaska, showing location of the Page Little Susitna district. . .

37. Sketch map and cross section of coal locality 1........ 127

38. Sections of coal beds in the Little Susitna district._........ 129 



\title{
MINERAL RESOURCES OF ALASKA
}

\section{GEOLOGY AND COAL RESOURGES OF THE LITTLE SUSITNA DISTRICT, MATANUSKA COAL FIELD, ALASKA}

\author{
By Farrell F. Barnes and Daniel Sokol
}

\section{ABSTRACT}

The Little Susitna district of the Matanuska coal field lies along the northern border of the lower Matanuska Valley in south-central Alaska. The Alaska Railroad at the west end of the district, and graveled roads leading to its south, east, and west edges, make the district easily accessible.

Three bedrock formations are known in the district. The oldest is mica schist, probably Precambrian, that was found in a small area; the second is the Arkose Ridge formation, consisting mainly of arkosic sandstone of probable Cretaceous age; and the youngest is an unnamed formation, probably Eocene in age, consisting of sandstone, siltstone, and claystone and including several beds of subbituminous coal. Except for a few outcrops along the larger streams, the district is entirely mantled by unconsolidated Quaternary deposits of glacial and alluvial origin.

The coal-bearing strata generally dip gently southward but are locally folded and faulted. They contain several beds of subbituminous coal, mostly less than 3 feet thick but including 1 impure bed at least 9 feet thick. Surface mapping in 1952 indicated that 4 localities, in addition to the Houston area where coal has been mined intermittently since 1917, contain 1 or more beds of potential stripping coal. Exploration of these 4 localities with a bulldozer and power auger in 1953 and 1954 indicated that the coal generally is too thin or impure to encourage mine development under present conditions. In the Houston area, diamond drilling by the United States Bureau of Mines in 1951 and 1952 showed that the upper 1,200 feet of the coal-bearing formation contains no more than 2 beds with as much as 3 feet of coal, and that these thin abruptly away from the outcrop.

\section{INTRODUCTION}

The Little Susitna district, as defined in this report, is an area of coal-bearing rocks ranging from 1 to 2 miles in width that extends for about 22 miles along the north side of the lower (west) end of the Matanuska Valley in south-central Alaska (fig. 36). The district is bounded on the north by the south front of the Talkeetna 


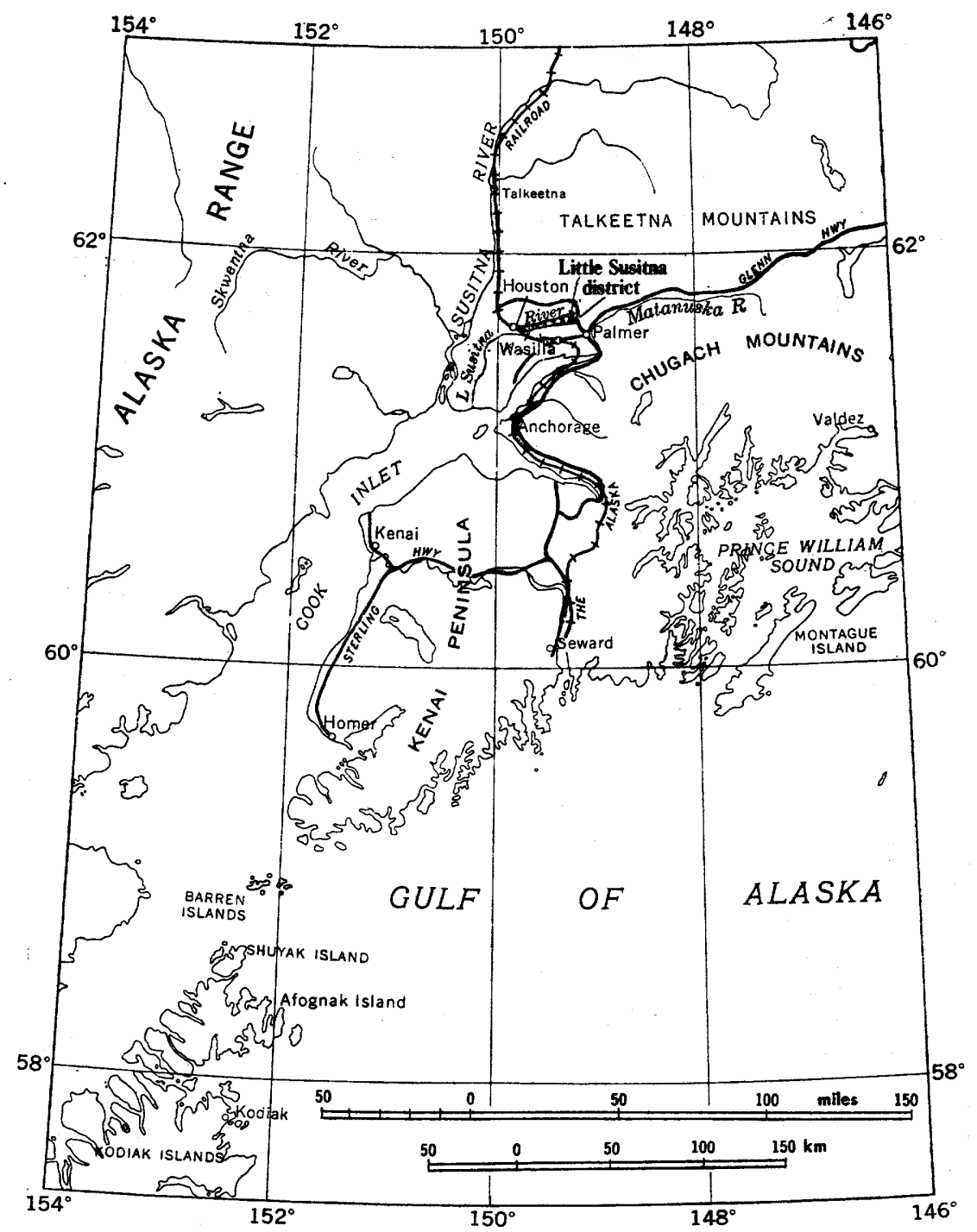

Frgorp 36.-Index map of south-central Alaska, showing location of the Little Susitna district.

Mountains, on the south and east by the Little Susitna River, and on the west by the broad Susitna River lowland. (See pl. 7.)

This report is based on preliminary surface mapping in the summer of 1952 and on subsurface exploration with a bulldozer powerauger unit in the summers of 1953 and 1954. In 1952 F. F. Barnes was assisted by Alfred Oestreich, geologist, and Lewis Ladwig and Richard Pack, field assistants. From July 2 to August 31, 1953, F. F. 
Barnes and Daniel Sokol were assisted by W. T. Ashlock and R. E. Rowland, field assistants, and by a bulldozer operator-mechanic. From June 23 to July 27, 1954, Barnes and Sokol were assisted by A. E. Burford and W. S. Hopkins, geologists, and an operatormechanic.

Prior to the present investigation very little was known of the geology of the district, except that it is largely covered with alluvial and glacial deposits, and that coal-bearing rocks had been reported at three widely separated localities. The purpose of the surface mapping was to determine the character, structure, and extent of the coalbearing rocks and to select the most promising areas for more detailed study. On the basis of this preliminary mapping four areas were selected for further investigation by subsurface methods. Detailed maps, showing the topography and location of trenches and drill holes in each area, were prepared and tied in with the land-survey net by planetable methods.

\section{GENERAL FEATURES}

Topographically the Little Susitna district consists of a series of benches or terraces, sloping gently southward, that extends from the foot of the Talkeetna Mountains to the Little Susitna River. The lowest bench is a flat gravel terrace about 30 feet above the level of the river flood plain, from which it is separated by a steep escarpment. The higher benches to the north are less well defined, and although generally covered with a veneer of gravel, they apparently were developed mainly on bedrock. All these benches are dissected by more than a dozen small tributaries of the Little Susitna River, which head on the southern slope of the Talkeetna Mountains and are incised to depths of 50 to 100 feet. The Little Susitna River, below the canyon through which it issues from the mountains, meanders widely across a flood plain averaging about half a mile in width and locally divides into two or more channels. Despite its meandering course the river has a rather steep gradient, characterized by an almost continuous succession of rapids and shoals.

The district has a maximum relief of about 850 feet, ranging in altitude from 250 feet at the west end to 1,100 feet at the foot of the mountains at the east end.

Most of the district is covered with a thick stand of trees, consisting mainly of birch and poplar on the well-drained benches, black spruce on poorly drained upland areas, and cottonwood and some spruce along the larger tributaries and on the river flood plain. West of Bench Lake, trees are limited to scattered clumps, the main cover consisting of low shrubs and grasses. 
Although the lower Matanuska Valley is near tidewater, it is so far from the open ocean that its climate is more typical of interior Alaska than of the coast. The summers are mild, and the winters are severe. Low temperatures are often accompanied by strong downvalley winds. The temperatures may rise well above $80^{\circ} \mathrm{F}$ in summer and drop below $-30^{\circ} \mathrm{F}$ in winter, but these extremes are exceptional. The average annual precipitation is about 16 inches. August and September are the wettest months, each with an average rainfall of almost 3 inches.

The east end of the Little Susitna district is accessible by graveled roads from Palmer and Wasilla, each about 10 miles distant. The west end of the district may be reached by a road from Wasilla to Houston and by the main line of The Alaska Railroad. A road to the Little Susitna River at a point about due north of Wasilla was under construction in 1955. The only roads within the district, aside from the highway to Houston, are the access roads built during this investigation, which extend for about 5 miles along the north side of the river below the mouth of Coal Creek.

\section{STRATIGRAPHY}

On the basis of scarce and widely scattered outcrops, three bedrock formations were recognized in or near the Little Susitna district. The oldest bedrock is a quartz-mica schist, probably Precambrian, which is exposed in a narrow gorge of Deception Creek about 5 miles due north of Houston (pl. 7). The second formation, which underlies the mountain slopes that form the north boundary of the district, consists of well-indurated conglomerate, arkosic sandstone, and shale that, at least locally, have been considerably affected by dynamic metamorphism. These rocks are evidently the westward extension of a sequence of arkose, shale, and conglomerate that is typically exposed in Arkose Ridge, east of the Little Susitna River, and that has been named the Arkose Ridge formation (Barnes and Payne, 1956, p. 10). Although these rocks were originally assigned an Eocene age on the basis of a few plant fossils, later evidence indicates that they probably are Cretaceous in age.

In the area between the mountain front and the Little Susitna River the bedrock consists mostly, if not entirely, of poorly to moderately indurated sediments comprising mainly fine to coarse pebbly sandstone, siltstone, and claystone, but including a few coal beds ranging from a few inches to at least 9 feet in thickness. Similarity in lithology and degree of induration to coal-bearing rocks of Tertiary age farther east in the Matanuska Valley indicates that these rocks are probably of Tertiary age also. Their total thickness is not 
known, but it is at least 1,200 feet at the west end of the district, as indicated by diamond drilling near Houston.

A 600-foot sequence of moderately indurated pebble conglomerate and sandstone, probably also of Tertiary age, is exposed in the southern part of the Little Susitna canyon, but its relation to the coalbearing rocks of the district has not been definitely established. The conglomeratic sequence dips $30^{\circ}-35^{\circ} \mathrm{S}$., and therefore would appear to underlie the nearest known coal-bearing rocks about a mile downstream. On the other hand, the conglomerate in the Little Susitna canyon appears to be identical lithologically with the Wishbone formation of Tertiary age, which, in the Wishbone Hill district a few miles to the east, overlies coal-bearing rocks of Tertiary age (Barnes and Payne, 1956, p. 18). These apparent relations suggest the possibility that the coal of the Little Susitna district belongs to a younger sequence, separated from the coal-bearing rocks of the Wishbone Hill district by the Wishbone formation. This conclusion is supported by the relatively lower rank of the coal and the lesser degree of induration and deformation of the coal-bearing rocks of the Little Susitna district; however, more information is needed to either establish or disprove the identity of the conglomerates in the two districts, and to determine the stratigraphic relation of the conglomerate and the coal-bearing rocks of the Little Susitna district. On the geologic map (pl. 7) the conglomeratic beds are included with the coal-bearing rocks.

The contact between the coal-bearing formation and older rocks was not found in the Little Susitna district. In the Little Susitna canyon, conglomerate of Tertiary age is exposed within a few hundred feet of highly disturbed arkosic strata of Cretaceous(?) age, but the structural relations and topographic expression indicate that they are separated by a major fault. West of the canyon the contact is concealed beneath Quaternary deposits, and its position can only be approximated between widely spaced exposures of the Arkose Ridge formation to the north and coal-bearing rocks to the south.

Three general types of unconsolidated deposits of Quaternary age are shown on plate 7. Glacial deposits, including both moraine and outwash, mantle the lowland south of the river and all but the lowest terrace north of the river. Gravel beds cover the lowest terrace on each side of the Little Susitna River, and alluvial deposits form the flood plain of the river.

\section{STRUCTURE}

The structure of the coal-bearing rocks in most of the Little Susitna district appears to be characterized by a moderate to gentle southerly 
dip, modified by slight folding. The steepest dips, $30^{\circ}-35^{\circ} \mathrm{S}$., were measured in the conglomeratic beds at the mouth of the Little Susitna canyon and in coal-bearing beds at localities 4 and 5 (pl. 7). Horizontal beds were mapped at two places in sec. 4 , T. 18 N., R. 1 E. Gentle synclinal folds are exposed in the west bank of the Little Susitna River at locality 1 and in the eastern part of sec. 6, T. 18 N., R. 1 E. (pl. 7). Coal beds at the Houston strip mine, at the west end of the district, $\operatorname{dip}$ about $4^{\circ} \mathrm{NW}$. As the dip at the nearest exposure to the east, at locality 5 , is $14^{\circ} \mathrm{SE}$, a northeastward-trending anticlinal axis may be inferred to pass north of locality 5 and south of the strip mine.

Comparatively few faults were observed in the Little Susitna district, which may be due more to scarcity of outcrops than to lack of faulting. The major fault that is inferred between the rocks of Tertiary age and those of Cretaceous(?) age in the Little Susitna canyon is in line with, and probably represents the westward continuation of, the Castle Mountain fault (Barnes and Payne, 1956, p. 9), which extends for many miles along the north side of the Matanuska Valley. Sheared zones and slickensides in the Arkose Ridge formation at several points near the base of the mountain front indicate that the Castle Mountain fault probably extends at least as far west as locality 3. Farther west the mountain front swings to the northwest, and the bedrock of the lowland and adjacent mountain slopes is completely mantled by glacial deposits. The only evidence of major faulting west of locality 5 is a low fault scarp that can be traced on aerial photographs for several miles across the lowland southwest of Houston. This fault, which has displaced the youngest glacial deposits, trends east-northeastward and passes about a mile south of Houston station, where it disappears under the alluvium of the Little Susitna River. Although this fault lies south of the expected position of the Castle Mountain(?) fault and presumably cuts the coal-bearing formation, it may nevertheless represent renewed movement along the same zone of weakness.

A fault with a displacement of about 10 feet was inferred at locality 1 to account for the difference in the altitudes of a coal bed in the outcrop and in drill hole 1 (fig. 37, section $A-A^{\prime}$ ). A major fault was exposed by trenching at locality 4 (pl. 8). This fault trends northeastward and dips steeply to the southeast. A thick gouge zone and the drag of bedding indicate that the southeast side was downthrown at least several tens of feet. Although no surface expression of this fault is apparent either in the field or on the aerial photographs, its position and trend indicate that it may be at least related to the fault south of Houston. A fault zone with a northerly trend and unknown displacement was also exposed in the northeast end of the Houston strip pit. 


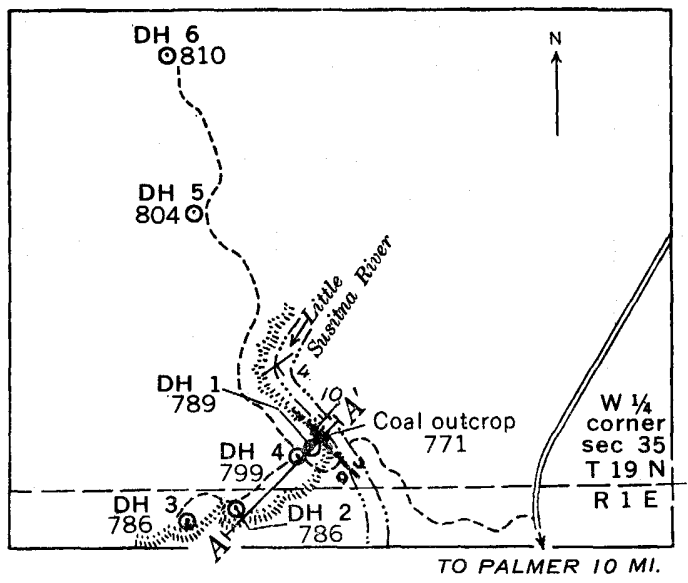

EXPLANATION

$K_{4}$

Strike and dip of beds

$\odot_{789}^{\mathrm{DH}}{ }^{1}$

Power-auger drill hole

Showing altitude in feet

Access road

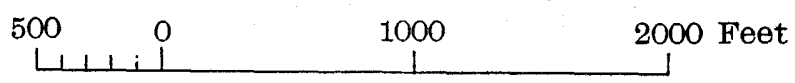
1

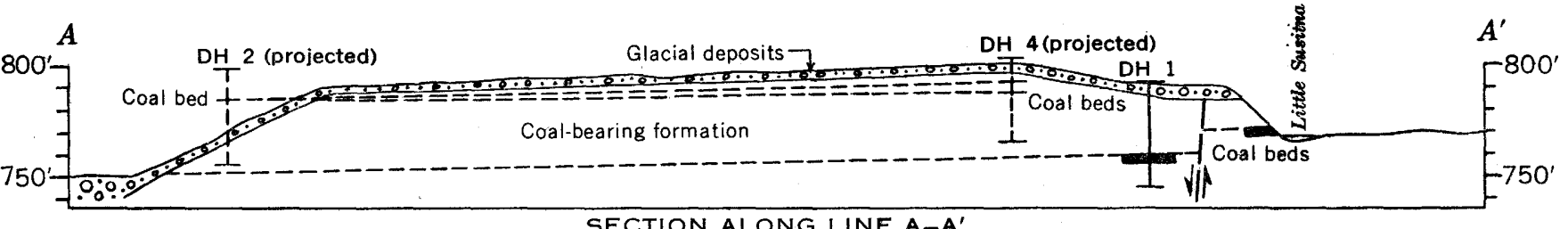

SECTION ALONG LINE A-A

Showing probable relations of coal beds in outcrop and drill holes 1,2 , and 4
100
100
200
300 Feet

Figure 37.-Sketch map and cross section of coal locality 1, Little Susitna district, Matanuska coal field, Alaska. 


\section{COAL}

\section{CHARACTER AND DISTRIBUTION}

The known occurrences of coal in the Little Susitna district are shown on plate 7, which also shows the probable minimum extent of the coal-bearing formation as inferred from outcrops and float in stream beds. Although coal was observed in place at only six widely scattered localities, it is possible, in view of the general scarcity of outcrops and the more widespread occurrence of coal float, that coal beds are more abundant and extensive than the few exposures would seem to indicate.

The coal apparently has about the same general character at all the outcrops. Each bed includes both bright and dull coal, and all the beds examined include one or more claystone partings or bony layers. The analyses in the table below indicate that the coal of this district is subbituminous B in rank, according to current standards of classification (Amer. Soc. Testing Materials, 1939). The samples from the strip mine were collected by R. R. May and F. F. Barnes in September 1950; the outcrop sample was collected by Barnes in July 1952. Sections of the beds from which the samples were taken are shown in figure 38.

Analyses of coal from the Little Susitna district, Matanuska coal field, Alaska

[Analyses by U. S. Bureau of Mines, Pittsburgh, Pa.]

\begin{tabular}{|c|c|c|c|c|c|c|c|c|c|}
\hline $\begin{array}{l}\text { Labora- } \\
\text { tory } \\
\text { No. }\end{array}$ & Location & Bed & $\begin{array}{l}\text { Condi- } \\
\text { tion } 1\end{array}$ & $\begin{array}{c}\text { Mols- } \\
\text { ture }\end{array}$ & $\begin{array}{l}\text { Vola- } \\
\text { tile } \\
\text { matter }\end{array}$ & $\begin{array}{l}\text { Fixed } \\
\text { carbon }\end{array}$ & Ash & Sulfur & $\begin{array}{c}\text { Heating } \\
\text { value, } \\
\text { Btu }\end{array}$ \\
\hline D-51894. & $\begin{array}{l}\text { Houston strip mine, } \\
1,200 \text { feet northeast } \\
\text { of old Evan Jones } \\
\text { tunnel. }\end{array}$ & Upper & $\begin{array}{l}\mathbf{A} \\
\mathbf{B} \\
\mathbf{C} \\
\mathbf{D}\end{array}$ & $\begin{array}{r}20.3 \\
13.7 \\
\hdashline \\
\hdashline\end{array}$ & $\begin{array}{l}31.6 \\
34.2 \\
39.6 \\
44.8\end{array}$ & $\begin{array}{l}38.9 \\
42.1 \\
48.9 \\
55.2\end{array}$ & $\begin{array}{r}9.2 \\
10.0 \\
11.5\end{array}$ & $\begin{array}{r}0.4 \\
.5 \\
.5 \\
.6\end{array}$ & $\begin{array}{r}9,210 \\
9,970 \\
11,550 \\
13,060\end{array}$ \\
\hline D-51895 & 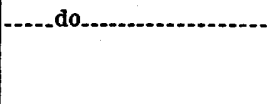 & $\begin{array}{l}\text { Lower } \\
\text { Houston }\end{array}$ & $\begin{array}{l}\mathbf{A} \\
\mathrm{B} \\
\mathrm{O} \\
\mathrm{D}\end{array}$ & $\begin{array}{r}17.4 \\
11.5\end{array}$ & $\begin{array}{l}32.5 \\
34.8 \\
39.3 \\
47.0\end{array}$ & $\begin{array}{l}36.6 \\
39.3 \\
44.4 \\
53.0\end{array}$ & \begin{tabular}{l}
13.5 \\
14.4 \\
16.3 \\
\hdashline-
\end{tabular} & $\begin{array}{l}.4 \\
.5 \\
.5 \\
.6\end{array}$ & $\begin{array}{r}9,160 \\
9,820 \\
11,090 \\
13,250\end{array}$ \\
\hline D-92673. & $\begin{array}{l}\text { Outcrop at locality } 3 \text {, } \\
1 \text { mile west of south- } \\
\text { west corner sec. } 7, \mathrm{~T} \text {. } \\
18 \mathrm{~N} \text {., R. } 1 \text { W. }\end{array}$ & Unnamed. & $\begin{array}{l}\mathbf{A} \\
\mathrm{C} \\
\mathbf{D}\end{array}$ & \begin{tabular}{r}
14.1 \\
\hdashline-1 \\
\end{tabular} & $\begin{array}{l}31.3 \\
36.4 \\
47.8\end{array}$ & $\begin{array}{l}34.1 \\
39.8 \\
52.2\end{array}$ & $\begin{array}{l}20.5 \\
23.8\end{array}$ & $\begin{array}{l}.4 \\
.4 \\
.5\end{array}$ & $\begin{array}{r}8,460 \\
9,850 \\
12,920\end{array}$ \\
\hline
\end{tabular}

1 Condition of sample: A, as received; B, air-dried; C, moisture-free; D, molsture- and ash-free.

\section{SUBSURFACE EXPLORATION}

\section{EQUTPMENT AND METHODS}

The equipment used for subsurface work consists of a small crawler tractor equipped with a power auger, and also with a hydraulically operated bulldozer blade that can be set at an angle for sidehill cutting during road-building and trenching operations. A heavy sled or 


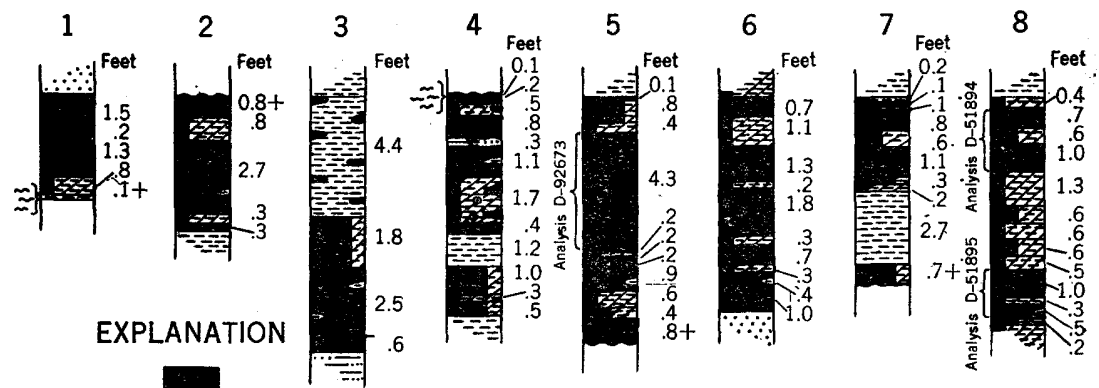

Coal

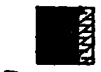

Bony coal

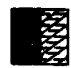

Bone

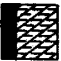

Coaly shale

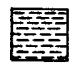

Claystone

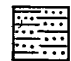

Siltstone

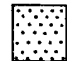

Sandstone

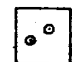

Ironstone concretions

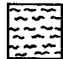

Clay or gouge

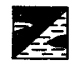

Rock and coal lenses

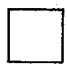

\section{SECTION COAL BED AND LOCATION}

1. Coal bed at locality 1 , in west bank of Little Susitna River

2. Coal bed 1 at locality 2 , in prospect tunnel on Coal Creek one-half mile above mouth

3. Coal bed 2 at locality 2 , in test pit on Coal Creek one-half mile above mouth

4. Coal bed 6 at locality 2 , in bulldozer cut near mouth of Coal Creek

5. Coal bed at locality 3 , in west bank of creek

6. Coal bed at locality 4 , in east bank of creek

7. Coal bed in Houston strip mine, near old Evan Jones tunnel

8. Coal bed in Houston strip mine, 1,200 feet northeast of old Evan Jones tunnel

Concealed interval

Frgorw 38.-Sections of coal beds in the Little Susitna district.

"go-devil," towed by the tractor, was used to transport fuel, lubricants, tools, and auger sections between drilling sites and also to move camp. A quarter-ton jeep equipped with extension body was used for transporting supplies over the rough access roads to the camp and drilling sites.

The drilling equipment used consists of a 4.5-inch spiral auger equipped with a drilling head fitted with 6 replaceable teeth. The auger consists of 4-foot sections joined by special hexagonal couplings that make possible rapid addition or removal of sections and also permit reversing the rotation of the auger to free a stuck bit. The maximum depth drilled in the Little Susitna district was 55 feet, but much greater depths can be reached under favorable conditions.

The following general procedure was used in exploring a given area. The initial drilling site was chosen as near as possible to a coal outcrop, where the expected depth to the coal could be readily estimated, and the thickness and character of the coal bed as determined from the drill cuttings could be checked by comparison with the exposed 
section. Logging of the drill holes requires almost constant examination of the drill cuttings as they emerge from the top of the hole because the auger is a continuous-sampling device. Two men were assigned to operate the drill-an operator-mechanic to handle the controls, and a geologist to $\log$ the hole and assist in adding and removing auger sections. Drilling was continued wherever possible through the lowest known coal bed within range of the auger, but in many holes the drill was stopped either by hard masses, mainly concretions, or by sticky wet claystone that would bind the auger and prevent its rotation. At many points boulders were found in the overburden, but in some holes, particularly at localities 1 and 2 (pl. 7), it was possible to force the drill past by applying heavy pressure with the hydraulic feed. If a boulder was too large to be forced aside, the drill was moved a short distance and a new hole started. The ease and speed with which this type of drill can be moved and a new hole started is one of its chief advantages. At localities 3 and 4 the overburden contained such a high proportion of cobbles and boulders that it was impossible to reach bedrock at any point without first stripping away most of the overburden with the bulldozer.

The location of drill holes was based on the position of coal beds as inferred from their attitude in nearby outcrops and modified by results of previously drilled holes. The objective was to outline areas underlain by potential stripping coal and to obtain as much information as possible on the thickness and quality of the coal and the depth of overburden. For detailed information on the coal it was necessary to rely on either natural or artificial exposures, and as natural exposures were scarce, the bulldozer was extremely useful in exposing coal beds at favorable localities as well as for exploration where excessive boulders in the overburden made drilling impossible.

\section{INTERPRETATION OF RESULTS}

The purpose of drilling is to determine the geologic structure and lithology when insufficient surface information is available. The ideal drill would furnish, quickly and inexpensively, a complete and accurate record of the thickness and character of the successive types of material penetrated. Core drilling obtains relatively complete and accurate information about the rocks penetrated, but it is slow and costly. With an auger-type drill, exactness of detail is sacrificed for speed and economy of operation; consequently, neither the thickness nor the character of the beds can be determined with a high degree of accuracy.

Perhaps the most difficult problem in this type of drilling is the determination of the depth at which the drill head passes from one 
type of material to another. The difficulty arises from the fact that by the time the cuttings from a particular depth have been brought to the surface, the drill head has advanced beyond the depth at which the cuttings originated, thus introducing an error in the recorded depth to the bed represented by the cuttings. The interval of rock that has been drilled while the cuttings are traveling to the surface, here called the lag interval, varies directly with the rate of drilling and the depth of the hole and inversely with the rate at which the cuttings move up the auger. Although the drilling rate and the hole depth can be measured, the rate of movement of the cuttings is less easily determined. In uniform material the rate of movement is fairly constant and the distance the drill advances while the cuttings are rising to the surface can be estimated with reasonable accuracy. However, uniformity rarely obtains, and variations in the character of the penetrated material-particularly the moisture content-greatly affect the rate of movement of the cuttings. Relatively dry cuttings move at a fairly rapid and uniform rate, whereas moist cuttings, particularly of clayey material, may adhere to the auger and may even block it. The lag interval in most holes must be estimated by taking into account such factors as the depth of the hole and the rate and constancy of the rise of cuttings from the hole. In general, the lag interval varies from 10 to 20 percent of the depth of the drill head, and the value used will depend on the observer's judgment of the rate at which the cuttings are moving to the surface. In some holes the passage of the drill from one bed to another can be detected by a change in the "feel" of the auger, from which the depth to the contact can be closely determined. Unfortunately, few of the coal beds drilled in the Little Susitna district differ sufficiently in hardness from the enclosing rock to be detected by "feel."

A second problem involved in this type of drilling is determining the lithologic character of individual beds, particularly the quality of the coal beds. Because of mixing and contamination of the cuttings as they move up the auger, accurate details of a bed rarely can be obtained from them. For example, it is difficult to determine whether a mixture of coal and rock fragments represents cuttings from a relatively clean coal bed with material from the roof and floor mixed with it, or from a dirty bed with several rock partings. For this reason trenching is a desirable supplement to drilling wherever practicable so that coal beds can be exposed for detailed measurements and sampling.

The power auger seems best adapted primarily to outlining areas of potential stripping coal and determining the thickness of overburden and secondarily to obtaining approximate information on 
the character and thickness of concealed coal beds. Although the equipment is reported by the manufacturers to be capable of drilling to depths of at least 100 feet, the value of the results obtained decreases rapidly with depth because of an increase in the lag interval and degree of contamination. Auger drilling is a valuable supplement to surface mapping and trenching, particularly in areas where the coal beds are largely concealed and lie at comparatively shallow depths. In the Little Susitna district, the maximum depth at which reliable data could be obtained was about 30 feet.

\section{DETAIIS OF COAL LOCALITIES}

\section{LOCALITY 1}

Locality 1 (fig. 37) is at the east end of the Little Susitna district in the unsurveyed part of T. 19 N., R. $1 \mathrm{E}$., in what would be the NW1/4 sec. 34. There the only known coal in the eastern part of the district is exposed in the west bank of the Little Susitna River at this locality, where a 3-foot bed (fig. 38 , section 1 ) has a strike of N. $45^{\circ}$ E. and a dip of $10^{\circ} \mathrm{NW}$.

It was impossible to determine if more coal is present below the gougy zone at its base. A short distance upstream from this locality the coal-bearing strata flatten and then rise gradually northward to form a gentle synclinal fold, but not far enough to re-expose the coal bed in the river bluff. The attitude of the beds indicates that the coal might underlie at relatively shallow depth a low terrace that extends westward from locality 1 . To check this possibility 4 auger holes, ranging in depth from 26 to 44 feet, were drilled along the edge of the terrace, and 2 more holes were drilled at points 1,000 and 1,600 feet northwest of the coal outcrop.

Drill hole 1, which was located as close as possible to the coal outcrop, passed through 3.5 feet of coaly material at a depth of 29.5 feet (pl. 9) or about 10 feet lower than the projected position of the coal in the outcrop. This discordance in position, together with the presence of shearing planes in the coal and rock of the outcrop, led to the conclusion that a fault, with the west side downthrown 10 feet, passes between the outcrop and drill hole 1 (fig. 37, section $A-A^{\prime}$ ).

Drill holes 2 and 3 were drilled near the edge of the terrace southwest of drill hole 1, but both were stopped by wet clay before reaching the 3-foot coal bed. Drill hole 2 passed through about 18 inches of coal at a depth of 8.5 feet; no coal was found in drill hole 3 . In an attempt to check the position of the 3-foot bed, drill hole 4 was put down 60 feet southwest of drill hole 1 . This hole passed through 2 thin coaly layers within 15 feet of the surface but was continued to 36.5 feet without reaching the 3 -foot bed. 
The probable relations of the coal beds and drill holes 1 to 4 are shown in section $A-A^{\prime}$ (fig. 37 ), which was drawn parallel to the strike of the beds exposed in the river bluff. The 3-foot bed lies about 40 feet below the surface of the terrace in the plane of the section and at even greater depth farther northwest.

Drill holes 5 and 6 (fig. 37) were put down to determine if the 3-foot bed might rise to the northwest on the north limb of the syncline indicated by the reversal in dip of the beds exposed in the river bank. They were drilled to depths of 38 and 36 feet, respectively, without finding coal (pl. 9). Swampy conditions prevented further exploration on the north limb.

\section{LOCALITY 2}

Locality 2 is near a small stream known locally as Coal Creek, on land formerly held by Emil Stadler and James Harris under a coalprospecting permit, in secs. 9 and 16, T. 18 N., R. 1 W. (pl. 7). The original discovery was made in 1917 by John Bartholf (Christensen, A., written communication, 1917), who drove a short prospect tunnel near the mouth of the creek and produced some coal for use at gold mines in the Willow Creek district, in the Talkeetna Mountains a few miles to the north.

In the present investigation 26 drill holes, ranging in depth from 18 to 55 feet, were put down to check the extent and depth of coal beds exposed in scattered outcrops, prospect pits, bulldozer trenches, and short tunnels along the lower half-mile of the creek. Locations and graphic logs of the drill holes are shown on plates 9 and 10 .

Correlation of drill holes and surface data indicates that the Coal Creek area is underlain by at least 6 coal beds, ranging in average thickness from 2 to 4 feet and including much bony material. The beds in the northern part of the area have a general southerly dip ranging from $13^{\circ}$ to $20^{\circ}$ and decreasing southward. Farther south, near the mouth of the creek, the dip as revealed by a single outcrop is $10^{\circ}$ SW. For convenience in reference, the principal coal beds in the northern part of the area are designated beds 1 to 5 , in ascending order. Although a southwestward-dipping coal bed near the mouth of the creek is separated from those to the north by a wide covered interval of rock, it was assumed to overlie them and was designated bed 6 .

The coal boundaries, where the coal is cut off at the bedrock surface, are shown on plate 10 . On the relatively flat uplands on either side of the creek valley the coal boundaries are concealed by 10 feet or more of surficial deposits. As the beds dip southward at a steeper angle than the land surface, the depth of overburden increases with the distance from the boundary (pl. 10, section $E-E^{\prime}$ ). 
Bed 1 is exposed in the creek bed and in a short prospect tunnel about half a mile above the mouth of Coal Creek, where it strikes due east and dips $18^{\circ} \mathrm{S}$. A section measured in the tunnel is shown in figure 38. To check the extent and depth of this bed below the flat uplands bordering the creek valley, 12 drill holes were put down west of the creek and 6 were drilled on the east side (pl. 10). In these holes bed 1 was traced along a strike length of 1,300 feet, at depths ranging from 10 to 46 feet. The bed was represented in the drill holes by coaly layers ranging from 1.5 to 9 feet in total thickness (pl. 9). A section parallel to the general strike of bed 1 is shown on plate 10 (section $\left.B-B^{\prime}\right)$.

Bed 2, estimated to lie about 60 feet above bed 1, had been opened in a short tunnel and in several test pits along the south side of the creek valley a short distance downstream from the prospect tunnel. The bed was found at a depth of 8 feet in drill hole 8 (pl. 9).. A section measured in the largest test pit is shown in figure 38 (section 3 ). At this point the bed strikes due east and dips $20^{\circ} \mathrm{S}$.

The log of drill hole 8 shows a total thickness of about 10 feet of coaly material ranging from coaly claystone at the top to clean coal at the base. This similarity to the measured section indicates that, at shallow depths, the auger gives a fairly accurate record of the character and thickness of penetrated coal beds. A section along the general strike of bed 2 is shown on plate 10 (section $C-C^{\prime}$ ).

Bed 3 lies between 100 and 150 feet above bed 2 and is partly exposed in an outcrop in the creek bed, in prospect pits on both sides of the creek valley, and in drill hole 17 . The bed includes at least 2 feet of clean coal in the outcrop and is represented by a 5-foot coaly layer in the drill hole; so it probably is between 3 and 5 feet thick.

Bed 4, which is about 25 feet above bed 3 in drill hole 17, was partly exposed in a deep bulldozer trench by the permittees. Drill hole 7, which was drilled in the bottom of the trench, cut through about 5 feet of coaly material, of which the upper 3.3 feet was judged to be coal and the remainder to be bone. Bed 4 is probably represented by coaly layers 3.5 and 4.5 feet thick, respectively, in drill holes 15 and 17.

Bed 5 was found only in drill hole 17, where it lies about 20 feet above bed 4. The drill cuttings indicate that the bed contains about 2 feet of relatively clean coal. A cross section along the strike of the beds through drill hole 17 is shown on plate 10 (section $D-D^{\prime}$ ).

Bed 6 is exposed in an outcrop and a short tunnel near the mouth of Coal Creek, and its eroded lower part was found beneath surficial deposits in drill hole 30 . To get a more complete section the bed was opened with the bulldozer in a sidehill cut (fig. 38 , section 4). The 
beds here strike $\mathrm{N} .40^{\circ} \mathrm{W}$. and $\operatorname{dip} 10^{\circ} \mathrm{SW}$. The stratigraphic interval between beds 5 and 6 could not be determined accurately because of lack of outcrops in the intervening area, but it is probably at least 100 feet.

\section{LOCALTTY 8}

Locality 3 is on unsurveyed land about a mile north of the Little Susitna River and a mile west of the west boundary of sec. 7, T. 18 N., R. $1 \mathrm{~W}$. The thickest coal bed found in the district is exposed for about 100 feet in the west bank of one of the larger tributaries, where section 5 (fig. 38) was measured. At this point the beds strike $\mathrm{N}$. $80^{\circ} \mathrm{W}$. and $\operatorname{dip} 7^{\circ} \mathrm{S}$.

Trenching was started on the west side of the valley, up the dip from the outcrop, to determine the extent of the bed and to further investigate the quality of the coal. A cut was bulldozed down the west bluff of the creek about 300 feet north of the outcrop in the hope of intersecting the coal bed near the surface of the upland west of the creek. However, trenching showed that gravel extends well below the projected position of the coal bed, indicating that the coal has been eroded at this point. A second cut was made about 150 feet north of the outcrop, and drill hole 33 was drilled to a depth of 25 feet from the lowest point in the cut without reaching bedrock. -The cut and drill hole together cut through about 15 feet of gravel and sand and 18 feet of clay. As the bottom of the drill hole was more than 50 feet below the top of the bluff it was concluded that no coal is present within stripping depth on the west side of the creek at locality 3.

Operations were then shifted to the east side of the creek, where coaly wash had been found in a shallow test pit in the bluff opposite the coal outcrop in the creek bank. At this location a bulldozer cut exposed a thin coaly layer; and drill hole 34 (pl. 9), in the floor of the cut, penetrated an 11-foot bed of coal and bone that is probably the same as the bed exposed west of the creek. Trenching on the projected trace of the bed at points 100 and 200 feet north of drill hole 34 exposed 15 to 20 feet of gravel without reaching bedrock. The cut at drill hole 34 was then deepened, and the coal was not only extremely dirty but cut off a few feet north of the drill hole at a steeply dipping contact with bouldery glacial clay, as shown in section $H-H^{\prime}$ (pl. 11). This evidence and the findings on the west side of the creek indicated that the coal at locality 4 has been eroded away north of a line passing just north of drill hole 34 and the outcrop, and that south of the line it is probably too deep and too poor in quality to be economically strip mined. 
Locality 4 is on unsurveyed land about a quarter of a mile north of the Little Susitna River and 2 miles west of the west boundary of sec. 18, T. 18 N., R. 1 W. There a 10-foot section of coal-bearing rocks was uncovered in the east wall of a small gully after its presence was revealed by abundant coal float in the creek bed. Section 6 (fig. 38) was measured at this exposure. The beds strike N. $70^{\circ} \mathrm{E}$. and dip $32^{\circ} \mathrm{SE}$. The character of the coal bed and its surface relations suggested that some of it might be minable by stripping. In order to determine if stripping were feasible, bulldozing and drilling were started on the slope above the coal exposure. The results are shown on the map and cross sections on plate 8 .

The first cut, about 100 feet up the projected trace of the coal bed from the outcrop, exposed sandstone and claystone with vertical dips and slickensided faces at its lower or west end. Drill hole 35 was put down in moderately dipping beds at the east end of this cut and passed through 13.2 feet of sandstone and fine sandy siltstone without finding coal. A trench to the east of the first cut exposed more than 5 feet of glacial till but did not reach bedrock. Sidehill cuts above the trench revealed coaly pockets in the lower part of the till, immediately above the bedrock, but no coal was found in place.

Vertical dips, slickensides, and the absence of coal in drill hole 35 indicate that the coal has been displaced by faulting. The northward steepening of dips at the outcrop and in the cuts suggests drag, which in turn indicates that the southern block was downthrown. Cross sections $J-J^{\prime}$ and $K-K^{\prime}$ (pl. 8), through the outcrop and drill hole 35 , show the probable relations of the coal and the fault.

On the west side of the creek valley, surface prospecting for the western extension of the coal bed revealed abundant coaly wash. A sidehill cut was made along the base of the slope to expose the coal and obtain more information on the structure. Instead of coal in place, the cut revealed a fault marked by a 30 -foot zone of gouge and brecciated bedrock, including an abundance of coaly material. On the north the fault has a sharp boundary with claystone of the coal-bearing formation; to the south it grades into undisturbed bedrock through a series of small slips. This fault zone is evidently the same as the one found east of the creek. The probable structure and position of the coal west of the creek are shown in section $I-I^{\prime}$ (pl. 8). According to this interpretation, the coal on both sides of the creek has been removed by erosion north of the fault and lies at too great a depth for strip mining south of the fault. 


\section{LOCALITY Б}

Locality 5 is near the center of T. 18 N., R. 2 W. (unsurveyed), on the second small stream east of Bench Lake (pl. 7). At one exposure a 10-foot section of interbedded claystone and sandstone includes a 1-foot coaly layer, of which the lower half is bright clean coal. The beds strike N. $55^{\circ} \mathrm{E}$. and dip $14^{\circ} \mathrm{SE}$. A short distance downstream a 20-foot section of sandstone and siltstone, including a few thin coaly layers and plant fragments, is exposed in a steep bluff. These beds strike N. $75^{\circ}$ E. and $\operatorname{dip} 35^{\circ}$ SE. As they are about on the strike of the beds at locality 4 and have a similar abnormally steep southeast dip, it is possible that they have been disturbed by the same southwestward-trending fault as observed at locality 4.

HOUSTON AREA

The only coal production of the Little Susitna district, aside from the small amount mined by Bartholf at locality 2 , has come from both underground and surface developments at the west end of the district near Houston. Coal in this area was first reported in 1917, when it was discovered by a grading crew in a railroad cut near the Little Susitna River. Between 1917 and 1920 several short tunnels were opened in the low bluffs along the northeast side of The Alaska Railroad between Houston station and the river. One tunnel near the station is reported to have produced at least 10,000 tons of coal from a 3.5-foot bed (Jones, personal communication, 1943). In 1937 a tunnel was opened by Evan Jones about a quarter of a mile northwest of Houston station. This tunnel was driven about 500 feet, and some coal was produced.

In 1948 the Houston Coal Co. began the development of a strip mine on a relatively flat-lying double coal bed, herein called the Houston bed, that had been traced by test pits and hand-drill borings for more than half a mile northeastward from the Evan Jones tunnel. Strip mining was done intermittently until 1954 and then suspended, largely because of increased thickness of overburden as mining progressed down the dip of the beds, which averages $4^{\circ} \mathrm{NW}$. The general character and thickness of the coal in the strip pit are shown in figure 38 (sections 7 and 8 ).

In 1951 and 1952 the U. S. Bureau of Mines drilled 3 diamond-drill holes in the vicinity of the Houston mine (pl. 7). Drill hole 1, near the strip pit, reached the Houston bed at a depth of 27 feet, passed through a bed containing 3.7 feet of clean coal at a depth of 297 feet, and was stopped at a depth of 482 feet without finding more coal.

Drill hole 2, about 1,000 feet northwest of the southwest end of the strip pit, reached the Houston bed at a depth of 175 feet, where it 
consists of 2 benches, each about 1.5 feet thick, separated by 5 feet of claystone. This hole was stopped at a depth of 1,142 feet after passing through several coaly layers, only one of which, at a depth of 985 feet, contained as much as 2.5 feet of coal.

Drill hole 3, about 3,000 feet northwest of drill hole 2, passed through 386 feet of coal-bearing strata, including 3 bony coal beds each less than 2 feet thick. The probable equivalent of the Houston bed, reached at a depth of 233 feet, consists of an upper 3.4-foot bed of coaly claystone and a lower 1-foot bed of bony coal separated by 6 feet of claystone. Tentative correlation indicates that drill hole 3 passed through about 80 feet of strata that overlie those in drill hole 2 , giving a known thickness of the coal-bearing formation of more than 1,200 feet.

Available data indicate that in the Houston area the upper 1,200 feet of the coal-bearing formation contains no more than 2 beds with as much as 3 feet of coal, and that these beds thin abruptly to the northwest.

\section{SUMMARY OF COAI RESOURCES}

The purpose of this investigation was to determine the presence or absence of minable deposits of coal in an area of coal-bearing rocks near transportation and within a relatively short distance of Anchorage, one of the principal markets for Alaskan coal. Although only a few parts of the area were studied in detail, all the known coal occurrences were included, and their wide distribution makes them fairly representative of the district. The results of the investigation indicate that all the coal beds probably are either too thin or impure to encourage development, at least under present conditions. The beds are too thin for underground mining and are not favorably situated for strip mining, except possibly in narrow belts near the outcrops of some of the beds on Coal Creek (loc. 2). Although some of the beds probably could be developed on a small scale for local use, it is doubtful that the reserves in any part of the district are sufficient to warrant the opening of a large commercial mine.

\section{REFERENCES CITED}

American Society for Testing Materials, 1939, Standard specifications for classification of coals by rank : ASTM Standards, pt. 3, p. 1-6.

Barnes, F. F., and Payne, T. G., 1956, The Wishbone Hill district, Matanuska coal field, Alaska : U. S. Geol. Survey Bull. 1016, 88 p. 

